\title{
SERGANČIŲJŲ PORTOPULMONINE HIPERTENZIJA DIAGNOSTIKOS, MEDIKAMENTINIO GYDYMO IR KEPENU TRANSPLANTACIJOS YPATUMAI
}

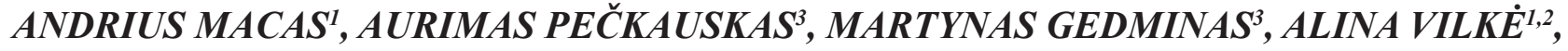 \\ DARIUS TREPENAITIS ${ }^{1}$, ARUNNAS GELMANAS ${ }^{1}$, JANIS ZINKUS ${ }^{1}$, LINAS PIETERIS \\ ${ }^{1}$ Lietuvos sveikatos mokslu universiteto Medicinos akademijos Anesteziologijos klinika, ${ }^{2}$ Lietuvos \\ sveikatos mokslu universiteto Medicinos akademijos Neuromokslu institutas, \\ ${ }^{3}$ Lietuvos sveikatos mokslu universiteto Medicinos akademija
}

\begin{abstract}
Raktažodžiai: plautine hipertenzija, portopulmonine hipertenzija, kepenu transplantacija, dešiniojo skilvelio nepakankamumas, plautinès arterijos kateterizacija, vazodiliataciné terapija.
\end{abstract}

\begin{abstract}
Santrauka
Šio straipsnio tikslas - apžvelgti portopulmoninès hipertenzijos patogenezès, klinikiniu išraišku, diagnostikos ir gydymo aspektus. Tobulejant bei plečiantis transplantologijos mokslui, portopulmonine hipertenzija tampa vis aktualesne problema. Maždaug 5-8\% kepenu transplantacijai ruošiamu pacientu pasireiškia ši patologinè büklè. Nustatyta, kad portopulmonine hipertenzija ženkliai didina komplikaciju, susijusiu su kepenu transplantacija, rizika bei blogina pacientu prognoze. Tik nuodugnus pacientu ištyrimas ir kompleksinis plaučiu kraujotakos hemodinaminiu parametru bei dešiniojo skilvelio funkcijos ịvertinimas leidžia parinkti optimalia gydymo taktika.

Siuo metu portopulmonines hipertenzijos patogeneziniai mechanizmai nèra iki galo išaiškinti, bet nustatyta, kad jos išsivystymui turi reikšmès plaučiu kraujagysliu endotelio pažaida, vazokonstrikciniu mediatoriu dominavimas, kraujagysliu remodeliacija ir tromboze.

Kol kas portopulmoninès hipertenzijos gydymo standardai yra „pasiskolinti“ iš kitu etiologiju plautiniu hipertenziju gydymo algoritmu, kadangi dar nera užtektinai perspektyviniu atsitiktiniu imčiu tyrimu bei visuotinai priimtu rekomendaciju. Svarbiausia grandies vieta šiuolaikiniame plautinès hipertenzijos gydyme sudaro vazodiliatacines medžiagos. Ankstyvas ir tinkamas medikamentinis gydymas daugeliui pacientu gali palengvinti simptomus, pagerinti bendra būkle ir netgi igalinti sekmingai atlikti kepenu persodinimo operacija.
\end{abstract}

\section{IVADAS}

Iprastai kraujotaka plaučiuose vyksta žemo spaudimo ir mažo kraujagyslių pasipriešinimo sąlygomis. Plaučių kraujagyslès yra labai elastingos, todèl net ir ženklus cirkuliuojančio kraujo tūrio padidèjimas nežymiai keičia spaudimą plaučių arterijoje. Prie tokių hemodinaminių parametrų yra prisitaikęs ir dešinysis skilvelis (DS). Todèl staiga didèjant spaudimui mažajame kraujo apytakos rate, DS plonasienis miokardas nesugeba adaptuotis prie pokyčių, o tai veda i dešiniųjų širdies kamerų išsiplètimą ir sąstovị didžiajame kraujo apytakos rate [1].

Dèl kepenų ligų išsivysčius portinei hipertenzijai, daliai pacientų pasireiškia patologinè būklè, vadinama portopulmonine hipertenzija (PPH), kurios metu dèl pokyčiu plaučių mikrokraujagyslèse padidejja vidutinis plaučių arterijos spaudimas (VPAS). Tai - viena iš plautinių komplikaciju sergantiesiems kepenu ligomis, kuri sukelia daug sunkumų, daro kepenu persodinimo (KTx) operaciją daug pavojingesnę, o kartais priverčia ir atsisakyti šios procedūros. Vis dèlto, didelei daliai sergančiuju medikamentinis gydymas gali pašalinti ar bent palengvinti minètą problemą, todèl labai svarbu, kad visi pacientai, ypač ruošiami KTx, būtų nuodugniai ištiriami dèl PPH.

Šiame straipsnyje aprašoma PPH patofiziologija, klinikinès išraiškos, diagnostika bei gydymo galimybès.

\section{TYRIMO OBJEKTAS IR METODAS}

Šaltiniai. Ruošiant ši straipsnį buvo apžvelgtos PubMed, Medline, Cohrane, Lippincott Williams \& Wilkins duomenų bazès ir jose esantys straipsniai apie PPH epidemiologiją, patofiziologinius išsivystymo mechanizmus, galimas klinikines išraiškas, diagnostikos ir gydymo metodus. Šios srities epidemiologiniai tyrimai, apžvelgiantys paplitimą ir ryši su kitomis patologijomis, Lietuvoje nebuvo atlikti, todèl remiamasi tik užsienio literatūros šaltiniais.

Sąvoka ir pagrindiniai teiginiai. PPH apibrēžimas suformuluotas po to, kai buvo aprašyti ịvairūs kepenų ligomis 
sergančiujjų hemodinaminių parametrų pokyčiai ir jų pasekmès. Tokių ligonių kraujotakos rodikliai esti kitokie nei normos atveju - jiems ịprastai randamas padidejęe širdies išmetimo tūris (ŠIT), kuris būna sąlygotas skysčiu persiskirstymo. Tokiu atveju padidèjęs VPAS gali būti vien dèl padidejusio cirkuliuojančio kraujo tūrio, todèl „,normalių“ hemodinaminių parametrų, sergant kepenu ligomis, išmanymas yra itin svarbus norint nustatyti pokyčius, sukeltus PPH.

Dèl minètų subtilumų PPH diagnozès patvirtinimui būtina atlikti dešiniosios širdies kateterizaciją (DŠK), kurios metu nustatoma, ar padideję̨s VPAS yra sukeltas būtent kraujo tèkmès obstrukcijos. Šiuo metu pacientams su portine hipertenzija PPH nustatoma remiantis šiais, DŠK metu gaunamais, hemodinaminiais parametrais[1]:

Padidejęs vidutinis plaučių arterijos spaudimas (VPAS): $>25 \mathrm{mmHg}$ ramybès ar $>30 \mathrm{mmHg}$ fizinio krūvio metu.

Normalus plaučių arterijos pleištinis spaudimas (PAPS) $(<15 \mathrm{mmHg})$ ar padidèjęs transpulmoninis gradientas (tPG) $(>12 \mathrm{mmHg}) . \mathrm{tPG}=$ VPAS - PAPS.

Padidejęs plaučių kraujagyslių pasipriešinimas (PKP): $>240 \mathrm{dyn} / \mathrm{s} / \mathrm{cm}^{-5} . \mathrm{PKP}=($ VPAS $-\mathrm{PAPS}) /$ ŠIT x 80.

Šiuo metu PPH yra skirstoma i lengvą (VPAS 25$35 \mathrm{mmHg}$ ), vidutinio sunkumo (VPAS $35-45 \mathrm{mmHg}$ ) ir sunkią (VPAS $>45 \mathrm{mmHg}$ ).

PKP padidejimas yra esminis kriterijus PPH diagnozei pagrịsti, tačiau esant neaiškioms situacijoms, būtent tPG padeda ịvertinti pasipriešinimą kraujo tekmei $[2,3]$. Pavyzdžiui, nors pacientas, kurio VPAS $38 \mathrm{mmHg}$, PAPS 18 $\mathrm{mmHg}$ bei PKP $209 \mathrm{dyn} / \mathrm{s} / \mathrm{cm}^{-5}$, ir neatitinka PPH diagnozès kriterijų, jos atmesti negalètume, kadangi tPG siekia $20 \mathrm{mmHg}$.

Apsvarstykime kitą pacientą, kurio VPAS yra $38 \mathrm{mmHg}$, PAPS $14 \mathrm{mmHg}$, PKP $218 \mathrm{dyn} / \mathrm{s} / \mathrm{cm}^{-5}$, o ŠIT 8,81/min. Apie $30-50 \%$ kepenų ciroze sergančiujų turi tokio tipo hiperdinaminę būklę (didelis ŠIT, bet mažas kraujagyslių pasipriešinimas) $[3,4]$. Tokių pacientų prognozė yra žymiai geresnè, nei sergančių tikraja $\mathrm{PPH}$.

Paplitimas. Bendraji PPH paplitimą įvertinti sudètinga, kadangi didžioji dalis rodiklių mus pasiekia tik iš KTx ruošiamų pacientų ištyrimo. Šaltinių teigimu, paplitimas tarp pacientų, sergančių kepenų ciroze su refrakterišku gydymui ascitu - 16,1\%, o tarp pacientų be refrakteriško ascito 0,25-4\% [5-7]. Apibendrinant apie 5-8\% KTx ruošiamų pacientų serga PPH ir turi padidejusią jos komplikacijų riziką $[8,9]$. Atsižvelgiant i šiuos teiginius, ruošiantis KTx operacijai būtina ịvertinti individualaus paciento $\mathrm{PPH}$ riziką.

Patofiziologija. PPH patogenezès mechanizmas nèra visiškai suprastas, tačiau jis apima kompleksinę keleto veiksniu sąveiką: vazoaktyviu mediatoriu disbalansą [10-12], endotelio pažaidą ir kraujagyslių remodeliaciją
$[13,14]$, lygiujų raumenų proliferaciją bei mikrokraujagyslių trombozę [15]. Pradinèse ligos stadijose vyrauja vazospazmas, o būklei progresuojant išsivysto negrịztami plaučiu kraujagysliu pakitimai, todèl svarbu pradèti medikamentini gydymą, kol jis dar gali būti efektyvus. Iki šiol nustatyti galimi PPH išsivystymo rizikos veiksniai yra: moteriška lytis, autoimuninis hepatitas, genetiniai sutrikimai estrogenų signalų perdavimo bei ląstelès augimo mechanizmuose $[9,17,18]$.

Plaučių endotelis, prisitaikydamas prie cirkuliuojančio tūrio pokyčių, nuolat išskiria didelius kiekius įvairių vaskulinių mediatorių, todèl jo funkcijos sutrikimas gali inicijuoti ịvairius kraujagyslinius pakitimus. PPH metu kraujyje randamos padidejusios tokių vazokonstrikcinių mediatorių kaip endotelino-1 (ET-1), angiotenzino I, tromboksano B2 bei prostaglandino $\mathrm{F}_{2 \text { alfa }}$ koncentracijos [19]. Be to, sumažeja ir vazodiliatacinių mediatorių (azoto oksido, prostaciklino) kiekiai, kas savo ruožtu skatina kraujagyslių proliferaciją ir remodeliaciją. Kitų mediatorių - noradrenalino, serotonino bei angiotenzino II - vaidmuo PPH išsivystyme dar nèra aiškus. Prie endotelio pažaidos ir kraujagyslių pakitimu prisideda ir vidaus organuose susidarę ịvairūs citokinai bei endotoksinai, kurie dèl portinès hipertenzijos ,apeidami“" kepenis patenka tiesiai ị plaučius [20]. Ši teiginị patvirtina tai, jog atstačius įprastą kraujotaką, kraujagyslių spazmas sumažèja.

Sirgusiujų PPH smulkiosiose plaučių arterijose randama ịvairaus laipsnio medijos hipertrofija, endoteliocitų proliferacija, spindžio fibrozè ir tromboze $[13,22]$. Šie pokyčiai identiški sergant pirmine plautine hipertenzija [8], todèl Pasaulio sveikatos organizacija PPH klasifikuoja toje pačioje kategorijoje kaip ir pirmines plautines hipertenzijas.

Vis dèlto, minèti pokyčiai plaučiu kraujagyslèse išsivysto ne visiems sergantiems kepenų ligomis, o ir portinès hipertenzijos laipsnis nekoreliuoja su PPH sunkumu [4]. Peršasi prielaida, kad egzistuoja dar nenustatyti genetiniai ar aplinkos veiksniai, turintys įtakos plaučiu kraujagyslių remodeliacijai. Šiuo metu atliekami tyrimai bando nustatyti kaulų čiulpų kilmės kamieninių ląstelių vaidmenį PPH patogenezèje.

Klinika ir diagnostika. Ankstyvose PPH stadijose pacientai gali neturèti jokių specifinių skundų, o objektyvaus tyrimo metu jiems bus nustatomi tik kepenų ligoms būdingi požymiai (teleangiektazijos, gelta, ascitas ir kt.). Ligai progresuojant atsiranda nuovargis, dusulys, širdies plakimai, krūtinès anginos epizodai, sinkopès, o dar vèliau - ryškẻja DS perkrovos ir nepakankamumo požymiai - periferinès edemos, Jungo venų pulsacija, dešiniujų širdies ribų išsiplètimas ir kiti. 
Visi pacientai, ruošiami KTx, turètų būti ištirti dèl PPH, kadangi ši patologija ženkliai didina perioperacinio mirštamumo riziką $[24,25]$. Tokie tyrimai kaip elektrokardiografija, krūtinès rentgenograma, betanatriuretinio peptido koncentracija kraujyje ar duju difuzijos tyrimas gali padèti ịtarti esamą plautinę hipertenzija $(\mathrm{PH})$, tačiau doplerinè echokardiografija turi būti atliekama kiekvienam pacientui, ruošiamam KTx [3]. Šiuo neinvaziniu metodu galima gana tiksliai nustatyti sistolinị spaudimą DS, tačiau tik su sąlyga, kad yra regurgitacinė tėkmė pro triburị vožtuvą (TV), kurios rodmuo ịtraukiamas į modifikuotą Bernuli (Bernuolli) lygti. Minèto tyrimo jautrumas ir specifiškumas diagnozuojant vidutinio sunkumo ar sunkią $\mathrm{PH}$ siekia atitinkamai $97 \%$ ir 77\% [26]. Doplerinès echokardiografijos metu nustatytas sistolinis spaudimas DS didesnis kaip 50mmHg yra indikacija DŠK. Apie 10-20\% atvejų TV nesandarumo nebūna, tuomet hemodinaminių parametrų mažajame kraujo apytakos rate neinvaziškai išmatuoti neįmanoma.

Kitas rodiklis, kuris galètų būti naudojamas DŠK atrankai, yra TV regurgitacinès tèkmès laiko integralas. Kuomet PKP viršija $120 \mathrm{dyn} / \mathrm{s} / \mathrm{cm}^{-5}$, šio parametro jautrumas ir specifiškumas diagnozuojant PH yra 100\% [27].

Kaip minèta anksčiau, PH sukèlusios priežasties diferencijacijai bei PPH diagnozès patvirtinimui yra būtina atlikti DŠK, tačiau ịprastų hemodinaminių parametrų nustatymas nèra toks svarbus kaip tikslus DS funkcijos įvertinimas $[28,29]$. Būtent nuo DS sugebejjimo prisitaikyti prie padidejusio PKP priklauso perioperacinių komplikacijų (donorinio organo persipildymas krauju ir funkcijos nepakankamumas) rizika ir bendra paciento prognozė [30]. Pavyzdžiui, kuomet spaudimas plautinejje sistemoje dideja pamažu ar ilgai išlieka stabilus (dèl medikamentinio gydymo ar lèto ligos progresavimo), DS turi laiko „sustipreti““ (hipertrofuoti) ir prisitaikyti prie didesnio krūvio sąlygų, o tokiems pacientams sèkmingiau atliekama KTx. Todèl tiksliai paciento rizikai nustatyti, be DŠK, reikalingi ir provokaciniai tūrio ar dobutamino mèginiai $[28,31]$.

Kraujagyslių reaktyvumo mėginiai sergant PPH nebūtini, kadangi „tikrieji“ vazodilatatoriai (kalcio kanalų blokatoriai, angiotenziną konvertuojančio fermento inhibitoriai) šios patologijos metu neskiriami dèl tokių šalutinių poveikių, kaip sisteminė hipotenzija ar kolapsas.

Gydymas. Pagrindiniai PPH gydymo tikslai yra VPAS bei PKP sumažinimas ir DS funkcijos stabilizavimas. Medikamentinis gydymas turètų būti pradedamas, prieš tai nuodugniai įvertinus DS funkcinę būklę, DŠK gautus hemodinaminius parametrus bei nustačius, kuriai Niujorko širdies asociacijos (NYHA) širdies nepakankamumo funkcinei klasei priklauso pacientas. Taip pat individualiu atveju būtina ịvertinti tokius veiksnius kaip skiriamų vaistų farmakologinès (hepatotoksiškumas) ir farmakokinetinès savybės, paciento galimybė bendradarbiauti gydyme (yra ar nèra encefalopatijos) ir kt.

Antikoaguliacine terapija veikia vieną iš $\mathrm{PPH}$ patogenezès grandžių, tačiau ją vertetu taikyti tais atvejais, kuomet nèra stemplès varikozių, trombocitopenijos, krešumo sistemos sutrikimų dèl kepenų disfunkcijos bei kitų galimų kontraindikaciju.

Ilgalaike oksigenoterapija, saturaciją palaikant ne mažiau kaip 90\%, turètų būti skiriama visiems PPH pacientams su hipoksemija.

Gydymas diuretikais koreguoja $\mathrm{PH}$ bei palengvina tokius ligos simptomus kaip ascitas ar periferinès edemos, tačiau neveikia PKP.

Beta-adrenoreceptoriu blokatoriai yra naudojami pirminei bei antrinei kraujavimo iš varikozinių mazgų profilaktikai, tačiau paskutiniai tyrimai parode, jog ju vartojimas ženkliai pablogino pacientų fizines galimybes bei plaučių hemodinamikos rodiklius [21]. Pasirodè, jog nutraukus beta - adrenoreceptorių blokatoriu naudojimą, 6 minučių ejjimo testo rezultatai pagerèjo 9 iš 10 pacientu bei $19 \%$ sumažèjo plaučių kraujagyslių pasipriešinimas. Tačiau ilgalaikio stebejjimo duomenys nebuvo publikuoti, todèl lieka neaišku, kaip ši intervencija pakeite kraujavimo iš virškinimo trakto dažnị. Vis dèlto, šiuo metu siūloma, jog beta - blokatorių terapija PPH metu turètų būti atsargiai apsvarstyta, o jei įmanoma - vengtina.

PPH gydyme svarbiausią grandị užima vazodilatacine terapija. Atsitiktinių imčių tyrimų, atliktų su sergančiaisiais PPH, kol kas nėra, tačiau yra surinkta daug informacijos apie jų teigiamą poveiki sergantiems idiopatine $\mathrm{PH}$ ar jungiamojo audinio ligų sukeltomis $\mathrm{PH}$.

Prostanoidai. Epoprostenolis - sisteminis vazodilatatorius ir trombocitu agregacijos inhibitorius. Šis preparatas teigiamai veikia PPH sergančiujų hemodinamiką ir fizines galimybes [23], tačiau duomenų apie ilgalaikị išgyvenamumą kolkas nèra. Keletoje klinikinių atvejų aprašomi $\mathrm{PPH}$ sirgę pacientai, kuriems skiriant šį vaistą sumažèjo plaučių kraujotakos spaudimo rodikliai ir buvo sèkmingai atliktos KTx [32-36]. Tačiau šis vaistas turi būti laikomas šaltai, prieš vartojimą specialiai paruošiamas bei skiriamas nuolatinès infuzijos būdu per centrinị kateterị - todèl jo naudojimas sukelia keblumų. Su epoprostenoliu taip pat siejamos tokios nepageidaujamos reakcijos kaip splenomegalija ar trombocitopenija.

Treprostiniliui nereikia specialių laikymo sąlygų, jo ilgesnis gyvavimo pusperiodis, tačiau jis vis tiek turi būti skiriamas nuolatine intravenine ar poodine infuzija. Techniškai šio vaisto vartojimas yra patogesnis, tačiau reikalingos didesnès jo dozès. Kitą prostanoidą, iloprostą, galima 
vartoti inhaliaciniu būdu, tačiau dèl labai trumpo pusinès eliminacijos periodo reikalingos 6-9 inhaliacijos per dieną.

Endotelino receptoriu blokatoriai. Bosentanas - blokuoja endotelino a ir b receptorius, taip užkirsdamas kelią vazokonstrikcijai. Manoma, jos šis vaistas sutrikdo tulžies drusku transportą ir taip sukelia ju kaupimąsi kepenu audinyje [37], todèl tinka PPH gydymui tik pacientams su lengvu kepenu funkcijos sutrikimu. Apie $10 \%$ pacientu gali padidèti kepenų fermentų bei bilirubino koncentracijos kraujyje [38], tačiau nutraukus vaisto vartojimą, daugeliu atvejų kepenų funkcija atsistato. Ambrisentanas - selektyviai blokuoja entodelino a receptorius. Skiriant ši vaistą taip pat reikalinga paciento stebėsena dèl kepenų fermentų ir bilirubino koncentracijų padidejimo. Tikslių duomenų apie šių preparatų naudingumą gydant PPH kol kas nèra [39-42].

Dar vienas galimas pasirinkimas - sildenafilis. Tai fermento fosfodiesterazès- 5 inhibitorius, kuris, gydant ịvairias PH formas, didina ŠIT bei mažina VPAS ir PKP, nesukeldamas rimtų šalutinių poveikių [43-45]. Aprašyti atvejai, kuomet sildenafilis sergantiesiems PPH ženkliai sumažino VPAS (nuo $>50$ iki $\sim 25 \mathrm{mmHg}$ ), kas leido sèkmingai atlikti KTx [46-49]. Kiti šaltiniai teigia, jog vartojant ši vaistą, keletui ligoniu pagerejo 6 minučiu ejjimo testo rezultatai, tačiau buvo ir tokių situacijų, kuomet PKP padidèjo [50].

Lengvos PPH gydymas yra diskutuotinas: daugeliu atvejų tokie ligoniai neturi jokių šiai patologijai priskirtinų simptomų, o jų funkcinè būklè išlieka pakankamai gera. Tuo tarpu ilgalaikis medikamentinis gydymas, sergantiems vidutinio sunkumo ar sunkia PPH, ženkliai pagerina pooperacinį išgyvenamumą ir pacientų prognozę [16]. Kaip minèta anksčiau, dèl išsamių atsitiktinių imčių tyrimų trūkumo dar nėra visuotinai priimtų PPH gydymo algoritmų.

Visiems PPH sergantiesiems šiuo metu yra rekomenduojamas gydymas diuretikais ir antikoaguliantais (jei nèra kontraindikacijų), tarptautinị normalizuotą santykị palaikant ties 1,5 (2C). Tuo tarpu, pradedant II NYHA funkcine klase, rekomenduojama pridèti ir vazodilatacinę terapiją, kurios veiksmingumas patvirtintas pirminès $\mathrm{PH}$ gydyme (2B). Dèl santykinai didesnès patirties PPH gydyme, šiuo metu rekomenduojamas preparatas - intraveninis epoprostenolis. Alternatyvūs pasirinkimai priklauso nuo to, kaip stipriai yra pažengęs širdies nepakankamumas:

II NYHA funkcinè klasė. Rekomenduojami preparatai: endotelino receptoriu blokatoriai (bosentanas, ambrisentanas) ar fosfodiesterazès-5 inhibitoriai (sildenafilis, tadalafilis).

III NYHA funkcinė klasė. Prie rekomenduojamų vaistu prisideda prostanoidai (epoprostenolis, treprostinilis ar iloprostas).
IV NYHA funkcinè klasė. Šioje stadijoje PH rekomenduojama gydyti intraveniniais prostanoidais. Nesant tokios galimybès, galimos daugkartinès iloprosto inhaliacijos.

Kepenų transplantacija. Vidutinio sunkumo bei sunki PPH ženkliai didina perioperacinių KT komplikacijų riziką $[49,50]$. Pavojingiausi operacijos etapai yra anestezijos indukcija ir donorinio organo reperfuzija, kuomet staigiai išauga spaudimas plaučių arterijoje, kas gali sukelti ūmų dešiniosios širdies nepakankamumą ir kraujo stazę persodintose kepenyse [30,51]. Gausi infuzoterapija ir staigus kraujo tèkmès pagreitèjimas kepenų reperfuzijos metu padidina VPAS bei PKP net ir neturejusiems PPH požymių prieš KTx [52].

Dèl šiu priežasčių būtina taikyti anksčiau paminètą PPH diagnostikos algoritmą visiem KTx ruošiamiems pacientams. Diagnozavus PPH ir sprendžiant dèl KTx, derètų remtis šiomis rekomendacijomis [53]:

Jeigu VPAS $<35 \mathrm{mmHg}$, PKP $<240 \mathrm{dyn} / \mathrm{s}^{\mathrm{c}} \mathrm{cm}^{-5}$, gera DS funkcinè būkle - rinktis KTx. Laukiant donorinio organo, skirti vazodiliatacinį medikamentinị gydymą, būklę vertinti kas 6 mènesius.

Jeigu VPAS tarp $35-45 \mathrm{mmHg}$, PKP $>240 \mathrm{dyn} / \mathrm{s}^{\mathrm{cm}} \mathrm{cm}^{-5}$, labai gera DS funkcinè būklè bei gerai toleruojami provokaciniai mėginiai - rinktis KTx, prieš tai skirant medikamentini gydymą. Jeigu DS funkcinè būklè prasta - atsisakyti KTx, skirti medikamentinị gydymą ir paciento būklę vertinti kas 6 ménesius.

Jeigu VPAS $>45 \mathrm{mmHg}$, PKP $>240 \mathrm{dyn} / \mathrm{s} / \mathrm{cm}^{-5}$ - skirti medikamentinį gydymą, stengiantis sumažinti VPAS $<35$ bei leisti DS sustiprèti. Būklę pakartotinai vertinti kas 6 mènesius.

Operacijos metu DS funkcinè būklè turètų būti stebima transezofaginès echokardiografijos būdu. Paskutiniais duomenimis, net ir stabilizavus PPH sergančiujų hemodinaminius parametrus medikamentinėmis priemonėmis bei laikantis KTx atrankos algoritmų, intraoperacinis mirštamumas siekia 14\% [59]. Literatūroje minimi keli atvejai, kuomet operacijos metu nustačius dèl staigaus VPAS padidèjimo išsivysčiusi ūmų DS nepakankamumą, padèjo agresyvi vazodilatacinè terapija inhaliuojamu azoto oksidu [51]. Minètų situacijų metu naudojami ir kiti vazodilatatoriai (prostaciklinas, diltiazemas, nitroglicerinas) bei širdies inotropinę funkciją gerinantys medikamentai (epinefrinas, dobutaminas, milrinonas) [60], tačiau aiškių tokių būklių gydymo rekomendacijų vis dar nèra.

DS nepakankamumui išsivysčius ankstyvu pooperaciniu periodu, ribojama infuzinè terapija, skiriami kilpiniai diuretikai bei jau minèti vazodilataciniai ir inotropiniai medikamentai. Aprašytas atvejis, kuomet pooperacinis DS nepakankamumas po KTx buvo sékmingai koreguotas mil- 
rinonu bei vazodilatatorių deriniu (epoprostenoliu, nitroglicerinu ir inhaliuojamu azoto oksidu) [61]. Vis dèlto, nepaisant griežtų KTx atrankos kriterijų ir šiuolaikinio gydymo, PPH sergančiujų perioperacinis mirštamumas, sukeltas progresuojančio DS nepakankamumo, sieka 36\% [59].

Kitas sunkia PPH sergančiųju gydymo pasirinkimas galètų būti kombinuota plaučių ir kepenų transplantacija. Šaltinių teigimu, po 10 tokių operacijų pacientų išgyvenamumas po 1, 3 ir 5 metų siekè atitinkamai 69, 62 ir 49\% [54].

Prognozè. PPH eiga priklauso nuo kepenų pažeidimo laipsnio ir plautinès hipertenzijos sunkumo. Pacientų, kuriems nepersodintos kepenys, vienerių metų išgyvenamumas siekia $85-88 \%$, trejų metų - $38-75 \%$ [55,56]. Retrospektyviniame tyrime, kuris apėmé $78 \mathrm{PPH}$ sergančius ir konservatyviai gydytus (nenaudojant prostanoidų) pacientus, išgyvenamumo mediana nuo diagnozès patvirtinimo buvo 6 mèn. (nuo 0 iki 84 mèn.) [53]. Širdies indeksas ir dešiniojo skilvelio funkcinè būklè yra svarbiausi prognostiniai veiksniai [22].

Kepenų persodinimas neišgydo PPH, kadangi daugeliu atvejų pokyčiai plaučiu kraujagyslèse būna ịsisenėję, todèl didžioji dalis pacientų ir po operacijos turi tęsti medikamentinį PPH gydymą [3,31]. Tačiau kartais plautinès hipertenzijos požymiai po kepenų transplantacijos palaipsniui dingsta - šis procesas grindžiamas atgaline plaučių kraujagysliu remodeliacija. Pastaruoju metu pasirodo pranešimų apie naujai išsivysčiusią $\mathrm{PPH}$ pacientams po kepenų transplantacijos [57]. Ši patologinè būklè pasižymi labai dideliu mirštamumu.

\section{APTARIMAS}

PPH - tai daliai kepenų ligomis sergančiujų (5-8\% ruošiamų KTx) pasireiškianti būklè, kurios metu ženkliai padidèja VPAS dèl padidejusio PKP. PPH ženkliai didina perioperacinių KTx komplikacijų riziką $[49,50]$, todèl visi pretendentai šiai procedūrai turètų būti nuodugniai ištirti $[24,25]$. Nors PPH ir išsivysto dèl portinès hipertenzijos, tačiau PH laipsnis nepriklauso nuo kepenų ligos sunkumo [4].

Apie 30-50\% sergančiujų kepenų ciroze turi hiperdinaminę kraujotakos būklę, kuomet dèl skysčiu persiskirstymo vyrauja padidèjęs cirkuliacinis tūris bei sumažejęs PKP $[3,4]$. Tuo tarpu PPH atveju spaudimas plaučių kraujotakoje pakinta dèl padidejusio PKP, kuri sąlygoja vazokonstrikcinių mediatorių vyravimas, endotelio pažaida, kraujagyslių remodeliacija ir tromboze [10-15]. Pradinèse PPH stadijose vyrauja kraujagyslių spazmas ir endotelio pažaida, vèliau inicijuojanti negrịžtamus plaučių kraujagyslių pokyčius.

PPH diagnozei patvirtinti būtini DŠK metu gaunami hemodinamikos parametrai: VPAS, PKP, PAPS ir tPG [1]. Indikacija DŠK laikomas doplerinès echokardiografijos metu nustatytas DS sistolinis spaudimas, didesnis kaip $50 \mathrm{mmHg}$. Tačiau, svarbiau už hemodinaminius parametrus yra ịvertinti DS funkcinę būklę, kadangi ji labiausiai koreliuoja su paciento prognoze ir KTx rizika $[28,29]$. Tam pasitelkiami provokaciniai tūrio ar dobutamino mėginiai.

Pradinèse stadijose PPH gali būti asimptomè, tokie pacientai turi tik specifinių kepenų ligoms skundų. Tačiau būklei progresuojant, atsiranda su DS perkrova ir nepakankamumu susijusios komplikacijos, kurios dažniausiai ir būna mirties priežastimi.

Dabartinès PPH gydymo rekomendacijos yra ,pasiskolintos“ iš kitų etiologijų PH gydymo algoritmų, kadangi kol kas nèra atlikta užtektinai perspektyvinių atsitiktinių imčių tyrimų, nagrinėjančių PPH terapijos aspektus. Iš vartojamų vaistų svarbiausią vietą užima vazodiliatatoriai: prostanoidai, angiotenzino receptorių blokatoriai, fosfodiesterazès-5 inhibitoriai. Paskutinių tyrimų duomenimis, beta-adrenoreceptorių blokatorių skyrimas pablogina fizinę paciento būklę, tačiau nèra duomenų, kaip jų terapijos nutraukimas veikia kraujavimo iš virškinimo trakto dažni [21]. Antikoaguliacinis gydymas PPH metu taikomas retai, dèl dažnų kontraindikacijų sergant kepenų ligomis.

Vidutinio sunkumo ir sunki PPH ženkliai didina perioperacinị KTx mirtingumą, todèl visi šiai operacijai ruošiami pacientai turi būti nuodugniai ištiriami. Tik kompleksinis plaučių hemodinamikos parametrų, DS funkcinès būklès ir atsako ị medikamentinị gydymą ịvertinimas leidžia teisingai ịvertinti paciento riziką ir prognozę. Šiuo metu daugelyje transplantologijos centrų nuolatinis VPAS $>50 \mathrm{mmHg}$ laikomas absoliučia kontraindikacija kepenų persodinimui. Pacientai, kurių VPAS svyruoja tarp 35 - $50 \mathrm{mmHg}$, taip pat pasižymi didesniais mirštamumo rodikliais, tačiau taikant priešoperacini gydymą galima ženkliai pagerinti jų būklę bei baigtis $[24,58]$. Tuo tarpu, pacientams, kurių DS funkcija yra normali ir plautine hipertenzija lengvos formos, kepenų transplantacija būna sèkminga [7].

KTx nèra PPH gydymo būdas, kadangi daugeliu atveju dẻl negrį̌tamų pakitimų kraujagyslèse spaudimas mažajame kraujo apytakos rate, negrižta ị normos ribas ir būna reikalingas ilgalaikis medikamentinis gydymas [3,31]. Vis dèlto, keletui pacientų po KTx spaudimas plaučių arterijoje palaipsniui normalizuojasi - tai aiškinama grị̌tama plaučių kraujagyslių remodeliacija.

Paskutiniu metu pasirodo pranešimų apie PPH išsivystančią de novo po KTx [57].

\section{APIBENDRINIMAS}

Portopulmoninė hipertenzija - tai viena iš kepenų ligo- 
mis sergantiesiems pasireiškiančių plautinių komplikacijų, kuri ženkliai pablogina bendrą pacientų prognozę bei padidina perioperacinių kepenų transplantacijos komplikacijų riziką. Siekiant optimalių rezultatų, visi pretendentai kepenų persodinimui turètų būti ištiriami dèl šios patologijos, o ją diagnozavus - atrenkami operacijai tik ịvertinus plaučiu kraujotakos hemodinaminius parametrus, dešiniojo skilvelio funkcinę būklę bei atsaką į medikamentinị gydymą.

Svarbiausią vietą portopulmoninès hipertenzijos medikamentinèje terapijoje užima vazodilatacinès medžiagos, tačiau dèl atsitiktinių imčių tyrimų stokos dar nèra visuotinai priimtų šios būklès gydymo rekomendacijų. Nepaisant griežtų diagnostikos ir atrankos kepenų transplantacijai algoritmų, portopulmoninè hipertenzija šiuolaikinèje medicinoje išlieka itin aktualia problema, kadangi perioperacinis tokių pacientų mirštamumas siekia beveik $40 \%$.

\section{Literatūra}

1. Afifi S, Shayan S, Al-Qamari A. Pulmonary hypertension and right ventricular function: interdependence in pathophysiology and management. Int Anesthesiol Clin 2009; 47:97-120.

2. Krowka MJ, Swanson KL, Frantz RP, et al. Portopulmonary hypertension: results from a 10-year screening algorithm. Hepatology 2006;44:1502-1510. of pulmonary hypertension. J Am Coll Cardiol 2004; $43: 5 \mathrm{~S}-12 \mathrm{~S}$

3. Rodriguez-Roisin R, Krowka M, Herve' P, Fallon M. Pulmonaryhepatic vascular disorders (PHD). Eur Respir J 2004; 24:861-880.

4. Hadengue A, Benhayoun MK, Lebrec D, et al. Pulmonary hypertension complicating portal hypertension: prevalence and relation to splanchnic hemodynamics. Gastroenterology 1991; 100:520-528.

5. McDonnell PJ, Toye PA, Hutchins GM. Primary pulmonary hypertension and cirrhosis: are they related? Am Rev Respir Dis 1983;127:437-441.

6. Cheng EY, Woehlck H. Pulmonary artery hypertension complicating anesthesia for liver transplantation. Anesthesiology 1992;77:375-378.

7. Castro M, Krowka MJ, Schroeder DR, et al. Frequency and clinical implications of increased pulmonary artery pressures in liver transplantation. Mayo Clin Proc 1996; 71:543-551.

8. Ramsay MA, Simpson BR, Nguyen AT, et al. Severe pulmonary hypertension in liver transplant candidates. Liver Transplant Surg 1997; 3:494-500.

9. Kawut SM, Krowka MJ, Trotter JF, et al. Clinical risk factors for portopulmonaryhypertension. Hepatology 2008; 48:196-203.

10. Kiely DG, Cargill RI, Struthers AD, et al. Cardiopulmonary effects of endothelin-1 in man. Cardiovasc Res 1997; 33:378-386.

11. Panos RJ, Baker SK. Mediators, cytokines, and growth factors in liverlung interactions. Clin Chest Med 1996; 17:151-169.

12. Higgenbottam T. Pathophysiology of pulmonary hypertension. Chest 1994; 105:7S-12S

13. Krowka MJ. Hepatopulmonary syndrome and portopulmonary hypertension: distinction and dilemmas. Hepatology 1997;25:1282-1284.

14. Hongqun L, Lee SS. Cardiopulmonary dysfunction in cirrhosis. Hepatology 2000; 14:600-608.

15. Lebrec D, Brenot F, Simonneau G, et al. Pulmonary arterial hypertension in portal hypertension. Eur Respir J 1998; 11:1153-1166.

16. Ashfaq M, Chinnakotla S, Rodgers L, et al. The impact of treatment of portopulmonary hypertension on survival following liver transplantation. Am J Transpl 2007; 7:1258-1264.

17. Roberts KE, Fallong MB, Krowka MD, et al. Genetic risk factors for portopulmonary hypertension in patients with advanced liver disease. Am J Respir Crit Care Med 2009; 179:835-842.

18. Roberts KE, Fallon MB, Krowka MJ, et al. Serotonin transporter polymorphisms in patients with portopulmonary hypertension. Chest 2009; 135:1470-1475.

19. Benjaminov FS, Prentice M, Sniderman KW, et al. Portopulmonary hypertension in decompensated cirrhosis with refractory ascites. Gut 2003; 52:1355-1362.

20. Hoeper MM, Krowka MJ, Strassburg CP. Portopulmonary hypertension and hepatopulmonary syndrome. Lancet 2004; 363:1461-1468.

21. Provencher S, Herve P, Jais X, et al. Deleterious effects of betablockers on exercise capacity and hemodynamics in patients with portopulmonary hypertension. Gastroenterology 2006; 130:120-126.

22. Edwards B, Weir K, Edwards WD, et al. Coexistent pulmonary and portal hypertension: morphologic and clinical features. J Am Coll Cardiol 1987; 10:1233-1238.

23. Swanson KL, McGoon MD, Krowka MJ. Survival in patients with portopulmonary hypertension [abstract]. Am J Respir Crit Care Med 2003; 167:A693

24. Krowka MJ, Plevak DJ, Findlay JY, et al. Pulmonary hemodynamics and perioperative cardiopulmonary-related mortality in patients with portopulmonary hypertension undergoing liver transplantation. Liver Transplant 2000; 6:443-450.

25. Swanson KL, Krowka MJ. Screen for portopulmonary hypertension, especially in liver transplant candidates. Cleve Clin J Med 2008; 75:121-136.

26. Kim WR, Krowka MJ, Plevak DJ, et al. Accuracy of Doppler echocardiography in the assessment of pulmonary hypertension in livertransplant candidates. Liver T ransplant 2000; 6:453-458.

27. Farzaneh-Far R, McKeown BH, Dang D, et al. Accuracy of Doppler-estimated pulmonary vascular resistance in patients before liver transplantation. Am J Cardiol 2008; 101:259-262.

28. Ramsay M. Liver transplantation and pulmonary hypertension: pathophysiology and management strategies. Curr Opin Organ Transplant 2007; 12:274-280.

29. Ramsay M. Portopulmonary hypertension and hepatopulmonary syndrome and liver transplantation. Int Anesthesiol Clin 2006; 44:69-82.

30. Ramsay M. Liver transplantation consideration and outcomes for the POPH patient. Adv Pulmon Hypertens 2004; 2:9-18.

31. Swanson KL, Wiesner RH, Nyberg SL, et al. Survival in portopulmonary hypertension: Mayo Clinic experience categorized by treatment subgroups. Am J Transplant 2008; 8:2445-2453.

32. Kuo PC, Johnson LB, Plotkin JS, et al. Continuous intravenous infusion of epoprostenol for the treatment of portopulmonary hypertension. Transplantation 1997; 63:604-616.

33. Krowka MJ, Frantz RP, McGoon MD, et al. Improvement in pulmonary hemodynamics during intravenous epoprostenol (prostacyclin): A study of 15 patients with moderate to severe portopulmonary hypertension. Hepatology 1999; 30:641-648.

34. Kähler CM, Graziadei I, Wiedermann CJ, Kneussl MP, Vogel W. Successful use of continuous intravenous prostacyclin in a patient with severe portopulmonary hypertension. Wien Klin Wochenschr 2000; 112:637-640.

35. Sussman N, Kaza V, Barshes N, et al. Successful liver transplantation following medical management of portopulmonary hypertension: a single-center series. Am J Transplant 2006; 6:2177-2182.

36. Fix O, Bass N, De Marco T, Merriman R. Long-term follow-up of portopulmonary hypertension: effect of treatment with epoprostenol. Liver Transpl 2007; 13:875-885.

37. Fattinger K, Funk C, Pantze M, et al. The endothelin antagonist bosentan inhibits the canalicular bile salt export pump: a potential mechanism for hepatic adverse reactions. Clin Pharmacol Ther 2001; 69:223-231. 
38. Rubin LJ, Roux S. Bosentan: a dual endothelin receptor antagonist. Expert Opin Invest Drugs 2002; 11:991-1002.

39. Hinterhuber L, Graziadei IW, Kahler CM, et al. Endothelin-receptor antagonist treatment of portopulmonary hypertension. Clin Gastroenterol Hepatol 2004; 2:1039-1042.

40. Clift PF, Townend JN, Bramhall S, et al. Successful treatment of severe portopulmonary hypertension after liver transplantation by bosentan. Transplantation 2004; 77:1774-1775.

41. Halank M, Miehlke S, Hoeffken G, et al. Use of oral endothelinreceptor antagonist bosentan in the treatment of portopulmonary hypertension. Transplantation 2004; 77:1775-1776.

42. Kuntzen C, Gulberg V, Gerbes AL. Use of a mixed endothelin receptor antagonist in portopulmonary hypertension: a safe and effective therapy? Gastroenterology 2005; 128:164-168.

43. Watanabe H, Ohashi K, Takeuchi K, et al. Sildenafil for primary and secondary pulmonary hypertension. Clin Pharmacol Ther 2002; 71:398-402.

44. Michelakis E, Tymchak W, Lien D, et al. Oral sildenafil is an effective and specific pulmonary vasodilator in patients with pulmonary arterial hypertension: comparison with inhaled nitric oxide. Circulation 2002; 105:2398-2403.

45. Ghofrani HA, Wiedemann R, Rose F, et al. Sildenafil for treatment of lung fibrosis and pulmonary hypertension: a randomised controlled trial. Lancet 2002; 360:895-900.

46. Makisalo H, Koivusalo A, Vakkuri A, et al. Sildenafil for portopulmonary hypertension in a patient undergoing liver transplantation. Liver Transplant 2004; 10:945-950.

47.Porres-AguilarM,Zuckerman M,Figueroa-Casas J,KrowkaM.Portopulmonary hypertension: state of the art. Ann Hepatol 2008; 7:321-330.

48. Gough M, White J. Sildenafil therapy is associated with improved hemodynamics in liver transplantation candidates with pulmonary artery hypertension. Liver Transpl 2009; 15:30-36.

49. Hemnes A, Robbins I. Sildenafil monotherapy in portopulmonary hypertension can facilitate liver transplantation. Liver Transpl 2009; 15:15-19.

50. Krowka MJ, Swanson KL. How should we treat portopulmonary hypertension? Eur Respir J 2006; 28:466-467.

51. Taura P, Garcia-Valdecasas JC, Beltran J, et al. Moderate primary pulmonary hypertension in patients undergoing liver transplantation. Anesthes Analges 1996; 83:675-680.

52. Kuo PC, Schroeder RA, Vagelos RH, et al. Volume-mediated pulmonary responses in liver transplant candidates. Clin Transplant 1996; 10:521-527.

53. Krowka M, Fallon M, Mulligan D, et al. Model for end-stage liver disease (MELD) exception for portopulmonary hypertension. Liver Transpl 2006; 12:S114-S116.

54. Grannas G, Neipp M, Hoeper M, et al. Indications for and outcomes after combined lung and liver transplantation: a single center experience on 13 consecutive cases. Transplantation 2008; 85:524-531.

55. Le Pavec J, Souza R, Herve P, et al. Portopulmonary hypertension: survival and prognostic factors. Am J Respir Crit Care Med 2008; 178:637-643.
56. Kawut SM, Taichman DB, Ahya VN, et al. Hemodynamics and survival of patients with portopulmonary hypertension. Liver Transplant 2005; 11:1107-1111.

57. Koch DG, Caplan M, Reuben A. Pulmonary hypertension after liver transplantation: case presentation and review of the literature. Liver Transpl 2009; 15:407-412.

58. Krowka MJ, Mandell MS, Ramsay MA, et al. Hepatopulmonary sindrome and portopulmonary hypertension: a report of the multicenter liver transplant database. Liver Transplant 2004; 10:174-182.

59. Krowka MJ, Mandell MS, Ramsay MAE, et al. Hepatopulmonary syndrome and portopulmonary hypertension: a report of the multicenter liver transplant database. Liver Transpl. 2004;10:174-182.

60. Csete M. Intraoperative management of liver transplant patients with pulmonary hypertension. Liver Transpl Surg. 1997;3(4):454-455.

61. Sulica R, Emre S, Poon M. Medical management of porto-pulmonary hypertension and right heart failure prior to living -related liver transplantation. Congest Heart Fail. 2004 Jul-Aug;10(4):192-4.

DIAGNOSIS, MEDICAL TREATMENT AND LIVER TRANSPLANTATION ASPECTS IN PORTOPULMONARY HYPERTENSION

Andrius Macas, Aurimas Pečkauskas, Martynas Gedminas, Alina Vilkè, Darius Trepenaitis, Arūnas Gelmanas, Janis Zinkus, Linas Pieteris Summary

Key words: portopulmonary hypertension, liver transplantation, pulmonary hypertension, right heart failure, right heart catheterization, vasodilator therapy.

The aim of this article is to review pathogenesis, clinical manifestestations, diagnostic and treatment aspects of portopulmonary hypertension. Together with increasing capabilities of transplantology rises the relevance of portopulmonary hypertension. It is estimated, that about 5-8\% of liver transplant candidates have this pathologic condition, which greatly increases the risk of perioperative complications and probability of poor outcomes. Only thorough examination of patient's pulmonary hemodynamic criteria and the condition of right ventricle can lead to the selection of the optimal treatment.

So far, the exact pathogenetic mechanisms of portopulmonary hypertension are not fully understood, but it is known that endothelial dysfunction, domination of vasoconstrictive mediators, vascular remodelation and trombosis play major role in this process.

Current treatment regimens used in portopulmonary hypertension are „, borrowed “ from algorithms used in pulmonary hypertension of other etiologies, since there aren 't enough perspective randomised trials available. Most important part in the management of portopulmonary hypertension is vasodilative therapy. Well-timed and proper treatment of this condition may ease the symptoms, increase the overall condition of the patient and even enable successful liver transplantation.

Correspondence to: aurimas.peckauskas@gmail.com

Gauta 2012-04-27 